RADOVI

UDK 7.071.4:373.542(497.523Varaždin)“1867/1918“

Zavoda za znanstveni rad

Pregledni članak

HAZU Varaždin

Review

BARBARA RIMAN

Primljeno: 23. 04. 2020.

Inštitut za narodnostna vprašanja, Ljubljana, Slovenija

Prihvaćeno: 08. 07. 2020.

barbara.riman@guest.arnes.si

DOI: $10.21857 /$ ygjwrcdgjy

JULIJA JANČEC

Filozofski fakultet u Rijeci

julija.jancec@hotmail.com

\title{
SLOVENSKI PROFESORI U VARAŽDINSKOJ GIMNAZIJI S POSEBNIM OSVRTOM NA RAZDOBLJE AUSTRO-UGARSKE MONARHIJE
}

Slovensko-hrvatske veze u povijesti školstva neistražena su tema u slovensko-hrvatskoj povijesti i u povijesti uopće. Povijest slovenstva na hrvatskom teritoriju počela se istraživati nedavno, a tema poput školstva i obrazovanja nije bila atraktivna niti hrvatskim niti slovenskim znanstvenicima. Profesori su u tom znanstvenom segmentu istraživanja, na određen način, bili zaboravljeni. Upravo se zato u ovom radu daje pregled djelovanja slovenskih profesora koji su bili aktivni u Varaždinskoj gimnaziji. Varaždinska gimnazija je, kao i neke druge gimnazije, imala vrlo važnu ulogu u obrazovanju i oblikovanju mladih generacija, te je osim profesora, koji su bili rođeni u slovenskim krajevima, u školi bio i veliki broj učenika iz slovenskih krajeva.

U radu se nije uspjelo prikazati djelovanje svih profesora jer nije bilo moguće pronaći niti osnovne informacije za njih, ali je prikazano djelovanje 16 slovenskih profesora koji su u Varaždinskoj gimnaziji djelovali u vrijeme Austro-Ugarske Monarhije.

U radu su navedeni profesori: Franjo Bradaška, Valentin Cajnko, Jernej (Bartol) Francelj, Josip Križan, Valentin Mandelc, Anton Rajšp, Franjo Selak, Josip Stare, Janez (Ivan) Trdina, Hinko Scheidela, Martin Senekovič, Matija Valjavec, Peter Valjavec, Martin Valenčak, Mihael Wurner, Luka Zima i Sebastijan Žepič. Istaknut je njihov doprinos u oblikovanju hrvatskog školstva u povijesti.

Ključne riječi: slovensko-hrvatske veze; Varaždinska gimnazija; Slovenci u Hrvatskoj; slovenski profesori. 
BARBARA RIMAN, JULIJA JANČEC: Slovenski profesori u Varaždinskoj gimnaziji s posebnim osvrtom na...

\section{UVOD}

Promatramo li slovensko-hrvatsku povijest, možemo uvidjeti da slovenskohrvatske veze kontinuirano rastu i razvijaju se već stoljećima. U tom povezivanju zamijećeni su različiti oblici suradnje. Prije svega, prevladavale su ekonomske veze, ali i neke druge veze imaju vrlo bitnu i važnu ulogu pri uspostavljanju međusobnih odnosa. Svakako je potrebno spomenuti intelektualne i obrazovne veze, a takvi se odnosi među dvjema zemljama oblikuju i danas.

Kada se govori o obrazovnim vezama, u njima važnu ulogu imaju obrazovne ustanove, odnosno, nastavni kadar koji predstavlja glavnog aktera obrazovnog procesa. Slovenski učitelji su bili poslani u različite krajeve državnih tvorevina u kojima su živjeli, upravo iz političkih razloga, ${ }^{1}$ a nekima od njih je migracija bila vlastiti izbor. Premještaji su bili uvjetovani dekretom koji se, osim na učitelje, odnosio i na svećenike, oficire i državne službenike. Irena Gantar Godina napominje da su to bile "pseudodobrovoljne“ migracije ${ }^{2}$ pa mnogi intelektualci na premještaj u Hrvatsku nisu gledali kao na kaznu. Zapošljavanje slovenskih učitelja i profesora u hrvatskim školama nije bila rijetkost, naročito nakon 1860. godine. Slovenci su često, nakon završenih fakulteta u Grazu i Beču, dolazili u pojedine hrvatske gradove kako bi se zaposlili u hrvatskim gimnazijama. ${ }^{3}$

Dobiti zaposlenje u željenom kraju bilo je izuzetno teško. Emilijan Lilek, i sam učitelj, nije mogao dobiti zaposlenje u nekom slovenskom kraju te je bio senzibiliziran za teškoće s kojima se susretao učiteljski kadar. ${ }^{4}$ Slične probleme imali su i profesori koji su djelovali u Varaždinu. Tako je Franjo Bradaška, dugogodišnji ravnatelj gimnazije u Varaždinu, opisao svoj dolazak u Hrvatsku ovako:

1 France KOBLAR, Četrta stran trikotnika: znameniti Slovenci in slovenska društva v Bosni in Hercegovini 1878-2000., Mladinska knjiga, Ljubljana, 2008., 16-17.

2 Irena GANTAR GODINA, „Slovenski intelektualci - Izseljenici na Hrvaškem: Jernej Francelj (18461921)“, Dve domovini ZRC SAZU, Inštitut za slovensko izseljenstvo in migracije, br. 24, Ljubljana, 2006., 157.

3 Branko ŠUŠTAR, „Poklicne migracije slovenskega učiteljstva od habsburških do jugoslovanskih časov“, Migracije in slovenski prostor od antike do danes, Zveza zgodovinskih društev Slovenije, gl. ur. Peter ŠTIH, Bojan BALKOVEC, Ljubljana, 2010., 209-224.

4 Lilek je već 1898. godine molio za mjesto u Kranju, ali mu nije bilo odobreno, a isto mu se dogodilo i s mjestom profesora u Novom Mestu. Kako mu se nije pružila prilika za rad na prostoru današnje Slovenije, razmišljao je o odlasku u Dubrovnik. Uz pomoć Mihovila Zavadlala, slovenskog prosvjetnog djelatnika koji je bio aktivan u Dalmaciji, nakon dugih je godina djelovanja u Bosni i Hercegovini došao u gimnaziju u Zadar. Nakon sedam godina djelovanja u Zadru, odlazi u mirovinu te se preselio u Celje. Tijekom cijelog svog radnog vijeka želio se preseliti u neko mjesto u Sloveniji (Barbara RIMAN, Kristina RIMAN, „Slovenci u Hrvatskoj gimnaziji u Zadru od 1897. do 1921. godine“, Zgodovinski časopis, Zveza zgodovinskih društev Slovenije, br. 3-4., Ljubljana, 2016., 350-351.). 
„Rojenja sem Slovenec. Dovršivši na Dunaji svoje nauke, zaprosil sem uplivnega moža pri vladi, ki mi je sicer bil prijazen in me je podpiral, naj bi me blagovoljno, namestil na Kranjskem, kjer bi želel posebno svojemu narodu služiti in koristiti; toda on me je zavrnil: Dam vas, kamor hočete, ali v Sibinj ali v Košice ali pa v Črnovice, v Ljubljano pa nikakor ne, ker je naše načelo, nedajati ljudi v domačo deželo. Ne hoteč oditi tako daleč od domovine, obrnil sem se potem do gospoda, ki je tedaj imel na Hrvaškem važno besedo v šolskih zadevah in me je poznaval še iz gimnazija v Ljubljani, ter ga zaprosil službe. Res jo dobim in postanem namestni, potem pravi učitelj, profesor in naposled gimnazijski ravnatelj. Uredim si svoj dom, in Hrvaška mi je postalo druga mila domovina“. ${ }^{5}$

lako je u Hrvatskoj djelovao velik broj slovenskih nastavnika, o njima se pisalo relativno malo. Podaci o nastavnom kadru još su uvijek relativno slabo obrađeni. Do sada ne postoji nijedan cjeloviti prikaz nastavnog osoblja koje je djelovalo na hrvatskom prostoru. Pozornost se pridavala samo nekim nastavnicima, koji su bili prepoznati kao važniji jer su se istakli kao pedagoški i prosvjetni djelatnici, odnosno, pažnju su dobili zbog neke druge aktivnosti. Cilj je ovoga rada prikazati uključenost profesora iz slovenskih krajeva u rad Varaždinske gimnazije.

Jedini autor koji je pokušao sistematizirati podatke o slovenskim nastavnicima u hrvatskim školama je Emilijan Lilek (1933.). On je izdao knjigu u kojoj je predstavio dio nastavnog osoblja koje je bilo na radu izvan slovenskih krajeva. Upozoravao je na velik broj nastavnika koji su radili i u hrvatskim krajevima te je poimence naveo 120 nastavnika. Za neke od njih daje i kratak prikaz njihova djelovanja, s tim da nije obuhvatio sve nastavnike, već samo jedan dio. Jednako tako, promatrajući nastavni kadar i njihovo djelovanje, knjigu završava s popisom što ga je uspio napraviti sve do 1932. godine.

Posebno mjesto u tom obrazovnom povezivanju imaju carske i kraljevske gimnazije u hrvatskim krajevima. Istaknuto je djelovanje profesora iz slovenskih krajeva koji su djelovali u gimnaziji u Pazinu ${ }^{6}$ i Karlovcu. ${ }^{7}$ Važne su bile gimnazije u Zagrebu te u Rijeci, a u ovom radu je naglasak na gimnaziji u Varaždinu.

Anton TRSTENJAK, Spomenik slovenske uzajemnost, Samozaložba, Ljubljana, 1886., 110-111.

6 Danijela JURČIĆ-ČARGO, „Slovenci na Hrvatskoj gimnaziji u Pazinu od 1899 do 1918.", Hrvatska gimnazija u Pazinu 1899-1999 : zbornik radovas međunarodnog znanstvenog skupa u povodu prve Hrvatske gimnazije u Istri, Zagreb - Pazin, 28.-30. listopada 1998., Gimnazija i strukovna škola Jurja Dobrile, Josip ŠIKLIĆ, Pazin, 1999., 367-382.; Barbara RIMAN, „Slovenski profesori u Carsko-kraljevskoj velikoj državnoj gimnaziji u Pazinu", Acta Histriae, Zgodovinsko društvo za južno Primorsko - Koper, br. 2., Koper, 2016., 357-380.

7 Silvin JERMAN, Slovenci Karlovcu Karlovac Slovencima 1579.-2009., Kulturno društvo Slovenski dom Karlovac, Gradska knjižnica "Ivan Goran Kovačić", Karlovac, 2012., 24-27. 
BARBARA RIMAN, JULIJA JANČEC: Slovenski profesori u Varaždinskoj gimnaziji s posebnim osvrtom na...

O slovensko-hrvatskim odnosima, ali i o razvitku slovenstva u sjevernoj Hrvatskoj, naročito Varaždinu, postoji suvremenija literatura. Valja navesti knjigu Filipa Škiljana iz 2015. godine, gdje je zabilježen detaljan pregled slovensko-hrvatske suradnje na prostoru Varaždinske županije. Svakako je važno spomenuti i rad Filipa Škiljana i Aleksandra Vukića o migracijama stanovništva na prostoru sjeverozapadne Hrvatske. Posebno se ističe rad Vladimira Huzjana, tiskan 2019. godine, o Slovencima u Varaždinu tijekom 1941. i 1942. godine, koji u svojem uvodnom dijelu daje i kratki pregled povijesne naseljenosti stanovništva iz slovenskih krajeva u Varaždinu. Osim navedenoga, postoje različiti drugi radovi koji su često hrvatsko-slovenske odnose spominjali parcijalno.

Gimnazija u Varaždinu djeluje kroz vrlo dugo razdoblje te je kroz nju prošao velik broj nastavnika, ali i učenika iz slovenskih krajeva. Prema nekim podacima, čini se da je u Varaždinskoj gimnaziji, od druge polovice 19. stoljeća pa do kraja prve polovice 20. stoljeća, djelovalo oko 25 profesora rođenih u slovenskim krajevima. ${ }^{8} \mathrm{O}$ tome svjedoči i zapis Janeza Trdine u njegovoj knjizi Bachovi Huzarji in Ilirci, gdje navodi: „On me je potolažil, da mi radi jezika ne bo treba si preveč beliti glavo. Dijaki me bodo lažje razumeli nego trde štokavske Hrvate. Dobra tretjina je štajerskih Slovencev, torej vaših rojakov, vsi drugi pa so bezjaki ali kakor zdaj pravimo Kajkavci, katerih narečje je bolj podobno vašemu nego ilirskemu jeziku“. ${ }^{9}$

\section{KRATKA POVIJEST VARAŽDINSKE GIMNAZIJE}

Varaždinsku su gimnaziju osnovali isusovci 1636. godine, u vrijeme kad je u Varaždinu postojao jaki protestantski pokret, a dolazak isusovaca bio je jedna od mjera za suzbijanje protestantizma. Među prvim gimnazijskim profesorima spominje se književnik Juraj Habdelić, zaslužan, između ostalog, i za ostanak gimnazije u Varaždinu, utoliko što se izravno usprotivio prijedlogu vodstva isusovačkog reda da se gimnazija preseli u Ptuj, pri čemu je isticao sve prednosti Varaždina. Nastavni plan i program Varaždinske gimnazije bio je nalik na planove i programe u drugim isusovačkim gimnazijama u Europi. ${ }^{10}$ Do izmjena dolazi tek u 18. st., za vrijeme vladavine carice Marije Terezije, kada pojedine predmete poučavanju predmetni profesori.

8 Emilijan LILEK, Slovenski v tujini službojoči šolniki, Samozaložba, Celje, 1933., 55.

9 Janez TRDINA, Bachovi Huzarji in llirci: spomini iz moje profesorske službe na Hrvaškem (1853-1867), Schwentner, Ljubljana, 1903., 7.

10 Nastava se održavala na latinskom jeziku, obrazovanje je trajalo šest godina, svake je godine jedan profesor predavao jedan predmet. 
Nakon ukidanja isusovačkog reda 1773. godine, Gimnaziju je nakratko preuzela Zagrebačka biskupija, ali već je 1776. godine bila predana pavlinima. Uskoro dolazi do sveukupne reforme, poznate kao Ratio educationis iz 1777. godine, po kojoj škola dolazi pod nadzor države. ${ }^{11}$ Pavlini su gimnaziju vodili do ukidanja njihovog reda 1786. godine. U 19. stoljeću Gimnaziju je zahvatilo više reformi, poput Ratio educationis 1807. godine te potom Thunova osnova. Najvažnija je ipak bila promjena pretvaranja gimnazije u osmorazrednu školu, i to četiri razreda niže gimnazije i četiri razreda više gimnazije, a nastava je konačno uređena kao predmetna, sa stručno-obrazovanim nastavnim kadrom. Ova se reforma u Hrvatskoj počela provoditi 1850. godine, a u Varaždinskoj gimnaziji od 1851. godine. $U$ to vrijeme Gimnaziju su vodili franjevci (1835.-1852.). ${ }^{12}$ Nastava se $u$ Gimnaziji sve više osuvremenjivala nabavkom nastavnih pomagala, osnivanjem predmetnih zbirki i obogaćivanjem knjižnice. Počinje se $s$ izdavanjem godišnjih izvješća pa je prvo bilo objavljeno 1853. godine. ${ }^{13}$

U 20. stoljeću je Gimnazija nastavila proživljavati razne reforme. Do 1910. godine Kraljevska velika gimnazija u Varaždinu djelovala je kao klasična, da bi se tada pokušala reformirati kao djelomično realna gimnazija, sve do kraja Prvog svjetskog rata.

Kraljevska velika gimnazija u Varaždinu je u razdoblju prije Prvog svjetskog rata pripadala tipu klasične gimnazije, a nakon rata pretvara se u realnu gimnaziju i mijenja naziv. Od školske godine 1920./1921. zove se Kraljevska realna gimnazija u Varaždinu, a još iste godine preimenovala se u Državnu realnu gimnaziju u Varaždinu. Taj program gimnazija će zadržati do kraja Drugog svjetskog rata.

Nakon Drugog svjetskog rata gimnazija je još neko vrijeme bila osmorazredna, a to će trajati do pretvaranja četverogodišnjeg osnovnoškolskog obrazovanja u osmogodišnje, što je započelo 1950. godine. U školskoj godini 1959./60. upisani su učenici sa završenim osmim razredom osnovne škole. Gimnazijsko obrazovanje od tada traje četiri godine. ${ }^{14}$

\footnotetext{
11 Vladimir PLETENAC, „Varaždinska gimnazija od 1636. do kraja Prvog svjetskog rata“, Gimnazija - SC „Gabriel Santo" Varaždin 1636. - 1986., Savjet SC "Gabriel Santo", gl. ur. Josip RUNJAK, Varaždin, 1986., 64.

12 Isto, 72.-79.

13 Đurđica CESAR, „Povijest Varaždinske gimnazije u prvoj polovini XX. st.“, Franjo Košćec i njegovo djelo: 1882.-1968., Zbornik radova sa znanstvenog skupa održanog 13. i 14. studenoga 2008. u Varaždinu, Hrvatska akademija znanosti i umjetnosti, Zavod za znanstveni rad Varaždin, Gradski muzej Varaždin, Gimnazija, Hrvatsko entomol. društvo, gl. ur. Miroslav ŠıCEL, Branko SPEVEC, Varaždin, 2008., 15.- 16.

14 Isto, 23.
} 
BARBARA RIMAN, JULIJA JANČEC: Slovenski profesori u Varaždinskoj gimnaziji s posebnim osvrtom na...

\section{ULOGA SLOVENSKIH PROFESORA U VARAŽDINSKOJ GIMNAZIJI}

Tijekom duge i burne povijesti Gimnazije u Varaždinu u njezinom je radu sudjelovao relativno velik broj profesora koji su svojim podrijetlom bili iz različitih dijelova Austro-Ugarske Monarhije, pa tako i iz slovenskih krajeva. lako se čini da je za vrijeme Austro-Ugarske Monarhije intenzitet slovensko-hrvatskih odnosa, koji se ovdje promatra, bio najintenzivniji, potrebno je naglasiti da su se oni nastavili i kasnije, ali zbog neistraženosti ove teme, nije moguće dati zaključke koliko je to na prostoru Varaždina i okolice i dalje bilo prisutno. Svakako je potrebno naglasiti da su slovenski i hrvatski pogranični krajevi, koji su tijekom Drugog svjetskog rata i nakon 1991. godine osjetili granicu, imali posebne procese (karakteristične za cijeli slovensko-hrvatski pogranični prostor). S obzirom na promjene nakon Prvog svjetskog rata, broj profesora i učitelja koji dolaze i djeluju u gimnazijama u Hrvatskoj se smanjuje, ali svejedno ostaje trajna prisutnost stanovništva iz slovenskih krajeva, gdje su osim nastavnog kadra svakako važnu ulogu su imali i učenici.

Kao što je već bilo napomenuto, o svim se profesorima nisu mogli pronaći cjeloviti podaci. Za neke čak nije bilo moguće pronaći niti osnovne podatke, o mjestu rođenja i smrti, pa je stoga ponekad teško procijeniti koliko su učinili za život Grada Varaždina. Neki pojedinci su uvršteni u ovaj članak jer su ih istraživači, koji su se bavili temama povezanima s Varaždinskom gimnazijom, povezali sa slovenskim krajevima. Najviše je o tim profesorima zapisao Emilijan Lilek na temelju literature koja mu je bila dostupna. Lilek je radio popis nastavnog kadra od vremena nastanka Austro-Ugarske Monarhije. Podatke o profesorima koji su radili u Gimnaziji u ranijem razdoblju, teže je pronaći. Neki od njih su: Jože Bukovec, Franjo Kornik, Jože Spendou, Gašpar Cenc, ${ }^{15}$ Štefan Jaklin, ${ }^{16}$ Matija Lazar, ${ }^{17}$ Alojz

15 Gašpar Cenc je bio svećenik, te je kao suplent radio školske godine 1853./1954. (Anton CUVAJ, Građa za povijest školstva, sv. 4., Trošak i naklada Kr. hrv.-slav.-dalm. zem. vlade, Odjela za bogošt. i nastavu, Zagreb, 1910., 287.). Nakon te školske godine dobio je mjesto kapelana te odlazi iz obrazovnog sustava (J. TRDINA, Bachovi Huzarji in llirci: spomini iz moje profesorske službe na Hrvaškem (18531867.), 8.

16 Štefana Jaklina u svojem popisu učitelja iz Slovenije navodi Emilijan Lilek, ali ne navodi nikakve druge podatke osim da je bio u Varaždinu od 1864. do 1866. godine. Iste te podatke navodi i Anton Cuvaj, te dodaje da je bio suplent od školske godine 1864./1865. do 1866. i potom od školske godine 1869./1870. (CUVAJ, sv. 5., 295.).

17 Matija Lazar (Kal, 1825. - ?), djelovao je kao svjetovnjak od školske godine 1855./1856. do 1865. kada je premješten u Goricu. (A. CUVAJ, Građa za povijest školstva, sv. 4., 287.). 
Kanc, ${ }^{18}$ Anton Postružnik, ${ }^{19}$ Mihael Prelog, Joža Zdravec, Franc Vračk (Wratschko), Kaspar Turin (Thurin), Rikard Ferdinand Ploh Herdvigov ${ }^{20}$ i Janko Zorko.

Neki su profesori, kako u Varaždinskoj gimnaziji, tako i u drugim gimnazijama, bili izuzetno aktivni tijekom svojega rada i izvan škole, tako da je njihovo javno djelovanje bilo lakše zabilježiti, nego što je to slučaj s profesorima koji su djelovali samo unutar škole. O njima se pisalo i hrvatski povjesničari su prikazali njihov rad koji je bio važan za grad Varaždin. Svakako je važno napomenuti da je i predmet koji su predavali, na određeni način, određivao u kojoj će mjeri pojedini nastavnik biti istaknut u javnosti. Profesori koji su predavali glazbu ili likovnu umjetnost mogli su lakše predstaviti svoju djelatnost široj javnosti nego profesori koji su predavali fiziku ili matematiku.

Neki su profesori u povijesti Varaždinske gimnazije, ali i Varaždina kao grada, ostavili veći trag, a za neke profesore bi bilo potrebno napraviti detaljniju analizu njegova djelovanja da bi se moglo u potpunosti ocijeniti njihovu ulogu $u$ povijesti. Posebno važnim se čini Anton Rajšp, koji je bio i ravnatelj gimnazije u Varaždinu. ${ }^{21}$

Mnogi su od profesora bili i učenici Gimnazije u Varaždinu i rado su se vraćali nazad kao profesori mlađim generacijama. Takvi su pojedinci ovdje predstavljeni s kratkim životopisima, prema abecednom redu.

18 Alojza Kanca u svojem popisu učitelja iz Slovenije navodi Emilijan Lilek, ali ne navodi nikakve druge podatke osim da je bio u Varaždinu od školske godine 1855./1856. do 1857., nakon čega je premješten u Osijek. Iste podatke donosi i Cuvaj (E. LILEK, Slovenski v tujini službojoči šolniki, 1933.; A. CUVAJ, Građa za povijest školstva, sv. 4., 287.).

19 Anton Postružnik, pronađeni su samo neki podaci: rođen 1825. u Sv. Jurij pri Pesnici, a umro 1909. u Zagrebu. Djelovao je u Varaždinskoj i Karlovačkoj gimnaziji (E. LILEK, Slovenski v tujini službojoči šolniki,1933.; A. CUVAJ,Građa za povijest školstva, sv. 10., 349.).

20 Rikard Ferdinand Ploh Herdvigov, folklorist (Pavlovec, 1846. - Varaždin, 1901.). Bavio se folklorom, bio je kritičar i pjesnik, a od 1871. do 1877. profesor na Varaždinskoj gimnaziji. Predavao je prirodne predmete, a po potrebi i njemački, latinski te matematiku. (Branka LEPEN, „Dijaki iz Ormoža in njegove širše okolice na Varaždinski gimnaziji v letih od 1851. do 1914.", u: Ormož skozi stoletja IV , gl. ur. Peter Pavel KLASNIC, Skupščina Občine Ormož, Ormož, 1993., 183.).

21 Rajšp, Anton, profesor (Ptuj, 1739. - Varaždin, 1786.). Više o njemu: Stanislav JUŽNIČ, "Isusovački stručnjaci u Varaždinu.", Radovi Zavoda za znanstveni rad Varaždin, Hrvatska akademija znanosti i umjetnosti, Zavod za znanstveni rad HAZU u Varaždinu, br. 26, Varaždin, 2015., 151.; Miroslav VANINO, Isusovci i hrvatski narod, Filozofsko-teološki institut Družbe Isusove, Zagreb, 1987., 393., 396-397., 427.; Vera KRŽIŠNIK-BUKIĆ, „O Slovencih in slovenstvu na Hrvaškem od nekdaj do danes“, u: Slovenci na Hrvaškem: dediščina in sedanjost, Zbornik referatov s posveta „Etnološka dediščina in kulturna podoba Slovencev na Hrvaškem, Slovensko etnološko društvo, gl. ur. Katalin MUNDA HIRNOK i Mojca RAVNIK, Ljubljana, 2006., 25.; Siniša HORVAT, „Knjižnica Varaždinske gimnazije“, Historia Varasdiensis, Društvo povjesničara grada Varaždina i Varaždinske županije, br. 1., Varaždin, 2011., 218. 
BARBARA RIMAN, JULIJA JANČEC: Slovenski profesori u Varaždinskoj gimnaziji s posebnim osvrtom na...

Bradaška, Franjo, povjesničar (Kranj, 1829. - Zagreb, 1904.). Nakon završenog studija odlazi u Hrvatsku, gdje je prvo djelovao u Zagrebu kao gimnazijski učitelj, a kasnije je bio profesor i ravnatelj Varaždinske gimnazije. Nakon obnašanja dužnosti ravnatelja u Varaždinskoj gimnaziji, postaje ravnateljem gimnazije u Zagrebu. Umirovljen je 1883. godine, odlazi u Graz, ali se ponovo vraća u Zagreb. Svoje povijesne tekstove počeo je objavljivati u „Slovenski Bčeli“, a za „Kmetijske in rokodelske novice“ preveo je na slovenski jezik djelo „Kratak pregled stare literature hrvatske“ („Kratek pregled starega slovstva hrvaškega“). U djelu „Slovenski gospodar“ opisivao je Zagreb. Bio je vrstan povjesničar, a radom u Hrvatskoj istaknuo se kao jedan od zaslužnih profesora koji su pripomogli pri oblikovanju hrvatskog školstva. Smatra se da je za hrvatske gimnazije priredio „Sravnajući zemljepis“, za više razrede srednjih razreda (Zagreb, 1867.), koji je bio posebno važan jer je s tim radom dao temelj suvremenoj hrvatskoj geografskoj terminologiji. ${ }^{22}$

Cajnko, Valentin, crkveni pisac, dobrotvor i gradski zastupnik (Ključarovci kod Ormoža, 12. 3. 1868 - Varaždin, 22. 7. 1925.). Maturirao je u Varaždinskoj gimnaziji 1887. godine. U Varaždinsku se gimnaziju upisao radi manjkavog znanja njemačkoga jezika, stoga ga nisu željeli primiti u gimnaziju u Maribor. ${ }^{23}$ Bogosloviju je završio u Zagrebu 1891. godine. Bio je kapelan u Pitomači, kateheta u Bjelovaru, a od 1897. godine radi kao kateheta u varaždinskim školama. Bio je društveno aktivan kao predsjednik Katoličkog djetićkog društva u Varaždinu, Društva za podupiranje siromašnih sugrađana te Potpornog društva za podupiranje siromašnih učiteljica. Bio je tajnik Društva za prehranu i Društva za potporu siromašne školske mladeži, te odbornik Gimnazijskog potpornog društva. Bio je biran i za varaždinskog gradskog zastupnika. Kao vjerski pisac pisao je pedagoške članke u Kršćanskoj školi i Dušobrižniku te tekstove na slovenskom jeziku u slovenskim listovima: „Ljubljanski zvon“, „Voditelji bogoslovnih vedah“, „Dom in svet“ i dr. Na hrvatskom jeziku pisao je pedagoške članke u Kršćanskoj školi (1910-1911., 1914.) i propovijedi u Dušobrižniku. ${ }^{24}$ Zanimljivo je i da je on kao vjeroučitelj zapisao ženidbene običaje te ih je objavio u djelu Stari ženidbeni običaj Pitomače" 1896. godine. ${ }^{25}$ Pisao je o hrvatskim običajima, a posebno o književnom doga-

22 Josip MAL, „Bradaška, Franjo (1829-1904.)“, Slovenska biografija. Slovenska akademija znanosti in umetnosti, Znanstvenoraziskovalni center SAZU, Ljubljana, 2013.; http://www.slovenska-biografija. si/oseba/sbi147766/\#slovenski-biografski-leksikon (5. ožujak 2020.).

23 Franci JUST, „Panonski portreti : iz slovstvene preteklosti med Rabo in Dravo“, 55, Vestnik, Valentin Cajnko", u: br. 40, 1998., 15.

24 Janko ŠLABINGER, „Cajnko, Valentin (1868-1925)“, Slovenska biografija. Slovenska akademija znanosti in umetnosti, Znanstvenoraziskovalni center SAZU, Ljubljana, 2013. http://www.slovenskabiografija.si/oseba/sbi154856/\#slovenski-biografski-leksikon (5. ožujak 2020.).

25 Valentin CAJNKO, „Ženidbeni običaji”, Zbornik za narodni život i običaje Južnih Slavena, Jugoslavenska 
đanju i o kazalištu, te su na taj način i slovenski čitatelji „Ljubljanskog zvona“ te „Doma in sveta" dobivali informacije o događanjima u Hrvatskoj. ${ }^{26}$

Francelj, Jernej (Bartol), ${ }^{27}$ novinar i izdavač, profesor (Čadrmska Vas blizu Poljčana, 1821.- Varaždin, 1889.). Osnovno obrazovanje stekao je u Poljčanima, u Celju i Mariboru. Šesti razred gimnazije dovršio je u Karlovcu te poslije upisuje licej u Grazu gdje boravi od 1842. do 1845. godine. Uz obavezne kolegije slušao je gospodarstvo, estetiku, slovenski i talijanski jezik. ${ }^{28}$ Teološki je studij započeo u Klagenfurtu, a 1845. u Pragu. Od 1850. do 1852. predaje u gimnaziji u Celju, zatim studira u Beču povijest, zemljopis i staroslavenski jezik do 1856. godine, kada u Varaždinu postaje učiteljem u Realnoj i glavnoj učioni, a 1873. profesorom u gimnaziji. Slovensku i hrvatsku narodnu ideju upoznao je tijekom školovanja. ${ }^{29}$ Tijekom školovanja počeo je pisati za praški list „Union“ i za "Slavenski jug“. Radi poticanja narodnoga gospodarstva pokrenuo je 1867. u Varaždinu tjednik „Pučki prijatelj“, kojemu je bio vlasnik i urednik do 1871. godine. List je politički bio uz Narodnu stranku, ali je pretežito sadržajem bio namijenjen gospodarskoj izobrazbi seljaka i obrtnika. Jernej je u pogovoru prvog broja napisao zašto je započeo izdavati list „Pučki prijatelj“: “za seljaka nije dosta skrbljeno, da on u mnogoj tjelesnoj i duševnoj stiski neima svega, što ga ide po ljudskom i Božjem pravu ..... ${ }^{30}$ Na njegov poticaj, Dragutin Stražimir u „Pučkom prijatelju“ objavljuje niz članaka o vinogradarstvu. Objavljivao je u periodicima "Slovenska čbela“, „Napreda“, "Narodne“ novine“, „Školski prijatelj", "Gospodarski list“ ,"Prijatelj naroda" i "Slovanski svet". Služio se pseudonimom Jernej Poljčanski i šifrom B. F. U Varaždinu je bio aktivan, te je zajedno s Josipom Križanom godine 1870. osnovao svoje društvo te su održavali edukativna predavanja. Sudjelovao je pri uspostavljanju Slovenske matice, bio je član Družbe sv. Mohorja, sv. Jeronimskega te član Matice hrvatske. ${ }^{31}$

akademija znanosti i umjetnosti, gl. ur. Ivan MILČETIĆ, Zagreb, 1896., , 178-184.

26 F. JUST, 15.

27 O njemu je pisao i Ivan KRIŽAN, „Jarnej Francelj,“ Kres, Tiskarna Družbe sv. Mohorja, br. 8., Ljubljana, 1885., 419-420.

28 Janko ŠLABINGER, „Francelj, Jernej (1821-1889)“, Slovenska biografija. Slovenska akademija znanosti in umetnosti, Znanstvenoraziskovalni center SAZU, 2013. http://www.slovenska-biografija.si/oseba/ sbi191156/\#slovenski-biografski-leksikon (16. ožujak 2020.).

29 Branko PLEŠE, Srećko LJUBLJANOVIĆ „FRANCELJ, Bartol Jernej“, Hrvatski biografski leksikon, Leksikografski Zavod Miroslav Krleža, Zagreb, 1998., http://hbl.lzmk.hr/clanak.aspx?id=6225, (20. veljače 2020.).

30 Irena GANTAR GODINA, „Slovenski intelektualci - izseljenci na Hrvaškem: Jernej Francelj (18211889)“, Dve domovini, Inštitut za slovensko izseljenstvo in migracije, br. 19., 2004., 175.

31 Isto, 166. 
BARBARA RIMAN, JULIJA JANČEC: Slovenski profesori u Varaždinskoj gimnaziji s posebnim osvrtom na...

Križan, Josip, pedagog (Kokoriči u župi sv. Križa kraj Ljutomera na Murskom polju, 1841 - Varaždin, 1921.). Podrijetlom je iz imućnije seljačke obitelji koja mu je, na poticaj njegova učitelja Roholeca, odlučila osigurati nastavak školovanja. ${ }^{32}$ Godine 1854. upisuje treći razred njemačke škole u Radgoni, koja će mu odrediti sljedeći korak obrazovanja, a to će biti Varaždinska gimnazija. Prvi razred upisuje 1855. godine, završava polaganjem ispita zrelosti 1863. godine. U gimnaziji istaknuo se u prirodoslovnim predmetima kod profesora Franje Folprechta. To ga je motiviralo da upiše studij matematike, fizike i filozofije u Grazu, umjesto studija teologije od kojeg je odustao nakon dva mjeseca. Roditeljeva želja bila je da im sin postane svećenikom, što je rezultiralo razočarenjem, pa se mladi Križan tijekom fakultetskog obrazovanja uzdržavao instrukcijama. Velika moralna podrška bio mu je bivši učitelj u Varaždinskoj gimnaziji, Martin Valenčak, koji je u međuvremenu premješten u Graz. Nakon trogodišnjeg studija prirodoslovnih predmeta, Josip Križan je u Grazu položio učiteljski ispit kojim je potvrdio svoju osposobljenost za rad u višoj i nižoj gimnaziji. Već je početkom školske godine 1867./1868. kao „pripravnik za gimnazijalno učiteljstvo” počeo raditi u požeškoj nižoj gimnaziji. Tu je proveo dvije početne godine svojeg službovanja tijekom kojih je, prema tadašnjem običaju, kao početnik predavao niz raznorodnih predmeta (matematiku, fiziku, prirodopis, povijest i njemački jezik). ${ }^{33}$ U Požegi je prvo stekao status namjesnog, a nakon toga pravog učitelja. Također, u Požegi se pripremao za stjecanje doktorata. Početkom školske godine 1869./1870., točnije 18. rujna 1869., Josip Križan je premješten u Varaždinsku gimnaziju gdje je ostao raditi sve do odlaska u mirovinu, 26 . listopada 1903 . godine. ${ }^{34}$

Za doktora znanosti filozofije promoviran je 1869. godine. Ravnateljem postaje 1899., kao najstariji član učiteljskog zbora, i tu je dužnost obavljao dva puta u razdobljima od tri mjeseca. Kulturni su djelatnici u Varaždinu u narodnoj čitaonici „Dvorana“ pokrenuli akciju javnih predavanja na hrvatskom jeziku, a predavanja su bila osobito važna za „varaždinske gospođe“. ${ }^{35}$ Tu ideju iz Zagreba preuzeo je Josip Križan koji je ujedno bio i inicijator takvih predavanja. Održao je prvo predavanje 18. ožujka 1870. godine na temu "O treptajućem gibanju i o Cortijevh vlakninah u uhu". Ova predavanja pratio je varaždinski tjednik „Pučki

32 Siniša HORVAT, „Prosvjetni i kulturni rad profesora Josipa Križana“, Časopis za suvremenu povijest, Hrvatski institut za povijest, br. 1, Varaždin, 2003., 249.

33 Isto, 250.

34 Isto, 251.

35 Đurđica CESAR, „Društveno-političke prilike u Varaždinu 60-tih i 70-tih godina XIX.st.“, Radovi Zavoda za znanstveni rad HAZU Varaždin, br. 25., Zavod za znanstveni rad HAZU u Varaždinu, Varaždin, 2014., 275-296. 
prijatelj“ kao i zagrebački „Vienac". Predavanja su bila vrlo posjećena, a prilikom Križanovog izlaganja 1870. godine "O uzdušnoj munjini" čak nije bilo slobodnih mjesta u gledalištu. Predavanja su se nastavila i 1871. kada je održao izlaganje na temu "O ustrojstvu oka i vida". ${ }^{36}$ Josip Križan bio je izuzetno društveno i kulturno aktivan. Bio je član: Matice hrvatske, Matice slovenske i Društva sv. Mohora u Celovcu. Pripada mu zasluga kao članu osnivačkog odbora Hrvatskog pjevačkog društva "Vila“, koje je skupina varaždinskih domoljuba osnovala 1875. godine, nasuprot pjevačkom društvu varaždinskih Nijemaca. Profesor Križan je na prvoj glavnoj skupštini Vile održanoj 26. ožujka 1876. godine, izabran za njezina prvog blagajnika. ${ }^{37}$ Križan nije zaboravio svoj materinski slovenski te je pisao i na njemu u glasilu "Kres" te u mariborskom učiteljskom glasilu "Popotnik". Jedno takvo djelo na slovenskom je „Logika prijateljem mudroslovlja“.

Mandelc, Valentin, pripovjedač i prevoditelj (Kranj, 1837. - Karlovac, 1872.). Njegov otac rođen je u Zapužu pri Begunjah na Gorenjskem, a u Kranju je kupio kuću. Majka je isto bila iz Gorenjske, iz mjesta Ljubno. Valentin je školu počeo pohađati u Ljubnom, a potom je školovanje na nastavio u Kranju. Srednju školu je nastavio 1847. godine u Ljubljani te ju je završio 1855. godine u velikom siromaštvu. Nakon gimnazije odlazi na studij u Beč gdje je studirao klasičnu filologiju i slovenski jezik. Na jesen 1859. godine odlazi za suplent, a u Varaždin, gdje se susreo s Valjavcem i Žepičem. Godine 1863. ponovo odlazi u Beč položiti ispite. Tamo je boravio neko vrijeme da bi potom bio u Kranju, a na kraju je dobio posao u gimnaziji u Karlovcu gdje je i ostao do smrti. Navodi se da je bio jedan od najomiljenijih i najuglednijih karlovačkih Slovenaca u 19. stoljeću. ${ }^{38}$ Cijeli život je bio vrlo boležljiv. Kada se promatra njegovo djelovanje u Hrvatskoj, može se reći da je Karlovac na njega i njegov život ostavio veći trag nego Varaždin. U Karlovcu je imao veliki ugled među profesorima. Sudjelovao je u radu pjevačkog društva „Zora" te je za društvo pohrvatio 11 pjesama. Bio je prijatelj Simona Jenka. Tijekom cijelog svog života pisao je i objavljivao pjesme, pripovijesti i crtice. Znana je njegova novela Tihotapec (1855). U Slovenskom glasniku je 1858. objavio i kasnoromantičnu pripovijetku "Jela“, a tamo je objavio i pripovijest „Ceptec“. U Karlovcu mu je 13. studenoga 1881. godine na groblju podignut spomenik.

Varaždin je važan u djelovanju Valentina Mandelca upravo zato što je tamo završio svoj prijevod prvog dijela Goetheovog Fausta, što je smatrao svojim naj-

\footnotetext{
36 S. HORVAT, „Prosvjetni i kulturni rad profesora Josipa Križana“, 253.

37 Isto, 253.

38 S. JERMAN, Slovenci Karlovcu Karlovac Slovencima 1579.-2009., 24.
} 
BARBARA RIMAN, JULIJA JANČEC: Slovenski profesori u Varaždinskoj gimnaziji s posebnim osvrtom na...

težim prijevodom. S tim je prijevodom želio pokazati premoć slovenskog jezika nad njemačkim, napisao je i uvod, ali nažalost, nije našao izdavača za taj svoj rad. ${ }^{39}$

Selak, Franjo, slovenski publicist, prevoditelj i povjesničar (Rečica v Savinjski dolini, 1847. - Zagreb, 1906.). Bio je pastir kod oca do 10. godine, a zatim je krenuo u osnovnu školu. Gimnaziju je pohađao u Celju od 1860. do 1868. godine. Studirao je u Grazu i u Beču. Kao suplent je radio u Varaždinskoj gimnaziji od 1873. do 1876. godine gdje je podučavao latinski, grčki, njemački, povijest i francuski jezik. Nadalje, odlučio je službovati u Rusiji, ali je prije samog odlaska iz Slovenije potrošio svu ušteđevinu pa je ostao u Grazu, gdje je bio učitelj i dopisnik Grazer Tagesposta. Neko je vrijeme podučavao u jednoj plemićkoj obitelji u Beču, a potom je otišao u vojsku. Bez posla i sredstva za život opet je bio 1880 . godine u Zagrebu te se zaposlio kao novinar Agramer Tagblatta. Godine 1893. zaposlio se u Sarajevu gdje je sudjelovao u uredništvu lista „Nada“, a bio je i urednikom vladinog političkog lista „Bosnische Post“. Od 1898. godine počeo je izdavati list „Stimmen aus Bosnien“ koji je nakon 6 mjeseci prestao izlaziti. Od 1902. do 1904. godine bio je nepotpisani urednik lista „Sarajevoer Nachrichten“. Uskoro se razbolio i zbog financijskih se poteškoća preselio u Zagreb te je nastavio raditi u uredništvu Agramer Tagblatta. Osim članaka u dnevnim novinama, napisao je nekoliko nepoznatih literarnih studija o slovenskim, hrvatskim, srpskim pjesnicima i piscima. ${ }^{40}$

Stare, Josip, povjesničar, publicist i propovjednik (Ljubljana, 1842 - Ljubljana, 1907.), školovao se u Ljubljani i u Rijeci gdje je i maturirao 1862. godine. U Rijeci je dobro naučio hrvatski, francuski i talijanski jezik te se zainteresirao za književnost. Studij slavistike, geografije i povijesti završio je 1866. godine u Pragu. Nakon studija vratio se u Ljubljanu, gdje je aktivno sudjelovao u kulturnom životu. Godine 1867. radio je kao profesor u Osijeku, a 1870. godine bio je profesor na Višoj gimnaziji u Požegi. Godine 1872. zaposlio se u Varaždinu. Tri godine kasnije bio je premješten na Višu realku u Zagreb, od 1881. do 1882. bio je privremeni ravnatelj gimnazije u Bjelovaru, a zatim ravnatelj zagrebačke Realne gimnazije. Nakon umirovljenja, 1904. godine, vratio se u Ljubljanu, gdje je živio do smrti. Starè je, živeći u Rijeci, svoje javno djelovanje usmjerio na zbližavanje

39 France, KOBLAR, „Mandelc, Valentin (1837-1872)“, Slovenska biografija. Slovenska akademija znanosti in umetnosti, Znanstvenoraziskovalni center SAZU, 2013. http://www.slovenska-biografija. si/oseba/sbi346226/\#slovenski-biografski-leksikon (16. ožujak 2020.).

40 Ljubomir Andrej LISAC, „Selak, Franjo (1847-1906)“, Slovenska biografija. Slovenska akademija znanosti in umetnosti, Znanstvenoraziskovalni center SAZU, 2013. http://www.slovenska-biografija. si/oseba/sbi558698/\#slovenski-biografski-leksikon (16. ožujak 2020.). 
Hrvata i Slovenaca. Surađivao je s brojnim slovenskim časopisima pišući radove o školstvu, javnom životu i kazalištu. ${ }^{41}$

Njegovi učenici imali su lijepa sjećanja na njega te je tako Janko Polec zapisao: „Bil je zelo vesten in priljubljen učitelj, ki je znal s svojo izobrazbo, z uglajenim nastopom in posebno s svojim pripovedniškim darom zbuditi zanimanje za predmet". ${ }^{42}$ Promatrajući njegovo opsežno djelovanje, potrebno je istaknuti da je bio vrlo plodan, a u svojim radovima je pisao upravo o potrebi za uvažavanjem i suradnjom dvaju različitih, ali po mnogim značajkama i vrlo sličnih naroda. ${ }^{43}$

Trdina, Janez (Ivan), književnik i povjesničar (Mengeš, 1830. - Novo Mesto, 1905.). Studij povijesti i zemljopisa završio je u Beču 1853., a potom je bio suplent u Varaždinskoj gimnaziji. Od 1855. godine bio je profesor u Rijeci te je tamo djelovao 12 godina. Nakon umirovljenja, iz političkih razloga 1867., preselio se u Novo Mesto. U periodici je objavljivao pripovijesti, basne, pjesme, putopise i memoare („Bajke i pripovijesti o Gorjancima“- „Bajke in povesti o Gorjancih“, 1882-88.; "Dolenjci“, 1884.; „Hrvatske uspomene“ - „Hrvaški spomini“, 1885.; "Bachovi husari i ilirci“ - „Bahovi huzarji in lliri“, 1903.; „Moj život" - „Moje življenje“, 1905.). Zanimljivo se čini spomenuti da je pisao o određenim procesima koji se danas povezuju s migracijama Slovenaca u Hrvatskoj i koje su značajne upravo za slovenske sezonske radnike, a on ih naziva "Hrvatarji“. ${ }^{44}$ Napisao je prvu povijest Slovenaca na slovenskom jeziku („Zgodovina slovenskega naroda“, 1866.). ${ }^{45}$ Kratko je boravio u Varaždinu, ali je okolnosti na koje je naišao detaljno opisao u svojem djelu „Bachovi Huzarji in Iliri“.

Scheidela, Hinko, profesor i pisac (Vitanje, Štajerska, 1874. - Zagreb, 1912.). Pučku školu i gimnaziju polazio je u Varaždinu i u Rijeci, a u Grazu je studirao latinski, njemački i grčki jezik. Od 1898. radio je kao suplent u gimnaziji u Varaždinu (1898.-

${ }^{41}$ France KOBLAR, „Starè, Josip (1842-1907.)“, Slovenska biografija. Slovenska akademija znanosti in umetnosti, Znanstvenoraziskovalni center SAZU, 2013. http://www.slovenska-biografija.si/oseba/ sbi604184/\#slovenski-biografski-leksikon (16. ožujak 2020.); Vera KRŽIŠNIK-BUKIĆ, „O Slovencih in slovenstvu na Hrvaškem od nekdaj do danes“, 2006, 65.; Kristina RIMAN, „Hrvatsko-slovenske veze u putopisima Josipa Starea", Slavistična revija, Slavistično društvo Slovenije, br. 1.,Ljubljana, 2017., 169182; Kristina RIMAN, „Slovenski pisci u Hrvatskoj kao graditelji slovensko-hrvatskih odnos“, Razprave in gradivo: revija za narodnostna vprašnja, Inštitut za narodnostna vprašanja, br. 80, Ljubljana, 2018., 48.

42 https://revija.ognjisce.si/revija-ognjisce/27-obletnica-meseca/1884-josip-stare (16. ožujak 2020.).

43 Kristina RIMAN, „Hrvatsko-slovenske veze u putopisima Josipa Starea“, 173.

44 Barbara RIMAN, Kristina RIMAN, "Hrvatarji u Slovenski književnosti“, Slavistična revija, Slavistično društvo Slovenije, br. 3, Ljubljana, 2016., 319.

45 Janez LOGAR, „Trdina, Janez (1830-1905.)“, Slovenska biografija, Slovenska akademija znanosti in umetnosti, Znanstvenoraziskovalni center SAZU, Ljubljana, 2013., http://www.slovenska-biografija. si/oseba/sbi719555/\#slovenski-biografski-leksikon, (11. ožujka 2020.). 
BARBARA RIMAN, JULIJA JANČEC: Slovenski profesori u Varaždinskoj gimnaziji s posebnim osvrtom na...

1901.), a kao profesor radio je na Sušaku (1901.-1903.). Od 1903. do smrti radio je u Zagrebu. Pisao je u „Nastavnički vjesniki“ o didaktičkoj metodi u obuci njemačkog jezika i književnosti, tumačio je Goetheova i Scillerova mladenačka djela te je pisao o praktičnom vježbanju njemačkog govora. Pisao je i za omladinski „Pobratim“. 46

Senekovič, Martin, profesor i pisac (Zgornja Ščavnica, 1837. - Zagreb, 1919.). Školu i gimnaziju završio je u Mariboru i Varaždinu (od 1851. do 1858.), a studirao je u Grazu. Kao suplent radio je u Varaždinu od 1863. do 1867. godine, a od 1867. godine bio je profesor u Vinkovcima, da bi od 1877. do 1880. godine bio i ravnatelj gimnazije. Dvije je godine djelovao u Gospiću, a potom je premješten u Zagreb, gdje je predavao u novoosnovanom ženskom liceju. ${ }^{47}$

Valjavec, Matija, (Srednja Bela, 1831. - Zagreb, 1897.) slovenski je pjesnik, folklorist i jezikoslovac. Kao prvorođenac, Matija je imao sedmero braće i dvije sestre. Započinje pohađati osnovnu školu 1838. u Kranju. Zbog slabe financijske situacije, morao se školovati sam. Osmi je razred završio u Ljubljani. Studij klasične filologije i slavistike završio je 1855. godine u Beču. Stanovao je s Janezom Trdinom i Sebastijanom Žepičem te je preživljavao tako što je poučavao na Fuhrmannovom zavodu. ${ }^{48}$ Od 1854. godine bio je srednjoškolski profesor u Varaždinu, a od 1876. u Zagrebu. Godine 1864. oženio se s Hrvaticom Bertom r. Ott te je imao mnogobrojnu obitelj- osam sinova i jednu kćer. Bio je redoviti član JAZU od 1879., tajnik 1893. i 1894. godine, a knjižničar od 1893. do 1897. godine. Surađivao je i u akademijinom Rječniku hrvatskoga ili srpskoga jezika, u kojemu je kratko bio i urednik (1884.). ${ }^{49}$ Znanstvene filološke radove objavljivao je na hrvatskom jeziku u Radovima JAZU. Počeo je pisati već u četvrtom razredu gimnazije kada su njegove pjesme prvi put bile objavljene. Preveo je Sofoklovog Ajanta, Seneku, Goetheovou Ifigeniju na Tauridi te Shakespeara. ${ }^{50}$ Njegova prva pjesnička zbirka „Pesmi“ izlazi 1855. godine. Rukopis je predao još prije diplome Janezu Bleiweisu te je zbirka objavljena prije njegova početka bavljenja peda-

46 SMOLEJ, Viktor, „Scheidela, Hinko (1874-1912.)“, Slovenska biografija. Slovenska akademija znanosti in umetnosti, Znanstvenoraziskovalni center SAZU, 2013., http://www.slovenska-biografija.si/oseba/ sbi540647/\#slovenski-biografski-leksikon (5. ožujka 2020.).

47 Ljubomir Andrej LISAC, "Senekovič, Martin (1837-1919)“, Slovenska biografija. Slovenska akademija znanosti in umetnosti, Znanstvenoraziskovalni center SAZU, 2013. http://www.slovenska-biografija. si/oseba/sbi561764/\#slovenski-biografski-leksikon (5. ožujak 2020.).

48 Vilim NOVAK, Jože TOPORIŠIČ, „Valjavec, Matija (1831-1897)“, Slovenska biografija. Slovenska akademija znanosti in umetnosti, Znanstvenoraziskovalni center SAZU, 2013. http://www.slovenskabiografija.si/oseba/sbi758091/\#slovenski-biografski-leksikon (15. ožujak 2020.).

49 http://enciklopedija.hr/natuknica.aspx?id=63799 (15. ožujak 2020.).

50 Viktor SMOLEJ, „Zapisek o Valjavcu“, Jezik in slovstvo, br. 1., Zveza društev Slavistično društvo Slovenije, Ljubljana, 1983., 24-29. 
goškim radom. ${ }^{51}$ Zamjerali su mu da si prisvaja tuđe sadržaje i postupke. Pjesnička zbirka iz 1855. godine u uvodnim stihovima nabraja tri inspirativna vrela: izazov mudrosti, zdenac božjih istina i lijek ranama srca. Taj je redoslijed tipična koncepcija takozvanih staroslovenaca koja je i temelj Valjavčeve versifikacije. ${ }^{52}$ Njegova najopširnija pjesma, koja sliči epu, jest „Zora in Sonca“. Matija Valjavec prvenstveno je bio folklorist koji upotpunjuje svoje pjesme individualnom kreativnošću stvaranja. U vrijeme svojega djelovanja u Varaždinu, Valjavec izdaje zbirku koja sadrži 119 proznih djela i 32 pjesme na kajkavskom..$^{53}$ Napisao je i epske pjesme te stihovane basne i pripovijesti („Pastir“, 1859.) koje su na stilskoj razmeđi romantizma i realizma.

Valjavec, Peter, klasični filozof (Srednja Bela, 1846. - Graz, 1909.), brat je Matije Valjavca. Osnovnu školu pohađao je u rodnom kraju, a gimnaziju od 1858. do 1866. u Varaždinu. Klasičnu filologiju studirao je u Beču i u Grazu od 1866. do 1869. godine. Bio je gimnazijski profesor latinskog, grčkog, njemačkog te starohrvatskog jezika. Kratko vrijeme bio je suplent u Varaždinu, a potom je djelovao u Slavonskoj Požegi (1869.-1875.), u Senju (1875.-1877.), u Osijeku (1877.-1886. i 1894.-1907.) te u Srijemskoj Mitrovici. ${ }^{54}$ Najveći dio svog života proveo je upravo u Osijeku. Opisuju ga kao osobu koja se klonila društva, ali je bio „miljenik soječkih đaka“. ${ }^{55}$

Valenčak, Martin, (Lastniču pri Polju, 1834. - Varaždin, 1864.), povjesničar književnosti. Otac mu je bio Jakob, a majka Apolonija r. Jagrič. Gimnaziju je završio u Mariboru (od 1848. do 1856.), nakon čega odlazi u Beč gdje studira klasičnu filozofiju (od 1856. do 1860.). Diplomirao je 1860. godine, a radio je kao gimnazijski profesor u Rijeci od 1860. do 1861. godine, u Varaždinu od 1861. do 1864. ., u Grazu od 1864. do 1870., te potom u Mariboru. Umirovljen je 1878. godine zbog tuberkuloze. Članke je objavljivao u slovenskim časopisima, a kao veliki narodnjak bio je jedan od suosnivača Matice slovenske (1864.) i Jugoslavenske akademije znanosti i umjetnosti (1867.). ${ }^{56}$

51 Jože POGAČNIK, "Matija Valjavec i njegovo književno djelo”, Radovi Zavoda za znanstveni rad Varaždin, Zavod za znanstveni rad HAZU Varaždin br. 14-15., Zagreb-Varaždin, 2004., 145-153.

52 Isto, 145-153.

53 Marija STATONIK, "Matija Valjavec”, Traditiones, Inštitut za slovensko narodopisje ZRC SAZU, br. 27, Ljubljana, 1998., 271-273.

54 Ljubomir Andrej LISAC, „Valjavec, Peter (1846.-1909.)“, Slovenska biografija. Slovenska akademija znanosti in umetnosti, Znanstvenoraziskovalni center SAZU, 2013. http://www.slovenska-biografija. si/oseba/sbi758994/\#slovenski-biografski-leksikon, (15. ožujak 2020.).

55 Anton CUVAJ, Građa za povijest školstva, sv. 6., 91.

56 Janko OROŽEN, „Valenčak, Martin (1834.-1887.)“, Slovenska biografija. Slovenska akademija znanosti in umetnosti, Znanstvenoraziskovalni center SAZU, 2013. http://www.slovenska-biografija.si/oseba/ sbi754627/\#slovenski-biografski-leksikon (15. ožujak 2020.). 
BARBARA RIMAN, JULIJA JANČEC: Slovenski profesori u Varaždinskoj gimnaziji s posebnim osvrtom na...

Wurner, Mihael, nastavnik (Ljubljana, 1829 - Feldhofu pri Gradcu, 1891.), rođen je od oca Mihaela i Marije r. Haass. Školu je pohađao u Ljubljani i to osnovnu od 1837. do 1840., a gimnaziju od 1840. do 1846. godine. Nakon toga je pohađao licej od 1846. do 1848. godine te je studirao teologiju od 1848. do 1853. godine. Ubrzo je napustio studij teologije te je otišao u Beč na studij prirodoslovlja i matematike od 1853. do 1856. godine. Bio je suplent u gimnaziji u Varaždinu od 1856. do 1861., zatim u Grazu, u Ljubljani na klasičnoj gimnaziji te u Kranju. Istovremeno je podučavao i na ljubljanskom učilištu. Zbog duševne bolesti, otišao je u prijevremenu mirovinu 1888. godine. Pisao je članke u školskim izvještajima. ${ }^{57}$

Zima, Luka, (Podlože, 1813. - Varaždin, 1906.) gimnaziju je završio u Mariboru, a zadnji razred 1853. godine u Zagrebu gdje se i upoznao s idejama ilirskog pokreta. Studirao je u Grazu i Pragu, a 1856. godine odlazi u Srijemske Karlovce. Tamo je predavao dvadeset godina. U Varaždin dolazi 1876. godine, gdje je radio šesnaest godina. Na poziv srpske vlade odlazi u Beograd gdje predaje grčki jezik u Velikoj školi u Beogradu. ${ }^{58}$ Srpski kralj Aleksandar mu je za četiri godine službe dodijelio orden sv. Save. Nakon umirovljenja vratio se u Varaždin. Njegovo najpoznatije djelo „Figure u našem narodnom pjesništvu: s njihovom teorijom“ (1880.), prva je sistematizacija figura i tropa hrvatskoga usmenoga pjesništva. Bio je član Jugoslavenske akademije, član Srpske matice u Novom Sadu i član Srpske akademije u Beogradu. ${ }^{59}$

Žepič, Sebastijan, gimnazijski profesor, filolog, slavist (Gozd pri Tržiču, 1829. - Varaždin, 1883.). Školovao se u Ljubljani, a tijekom školovanja stanovao je s Matijom Valjavcem i Janezom Trdinom. Gimnaziju završava u Ljubljani 1851. godine. Kao odličan učenik, zajedno s Matijom Valjevcem odlazi u Varaždinsku gimnaziju gdje radi kao pripravnik jedanaest godina, a kasnije ostaje raditi u toj istoj gimnaziji gotovo šesnaest godina. ${ }^{60}$ Predavao je latinski i staroslovenski iz novoslovenskog jezika. Godine 1871., Žepič dobiva službu u Novom Mestu gdje je ostao dvije godine te se nadao da će nakon toga dobiti namještenje u Ljubljani. No, to se nije dogodilo nego je premješten u Zagreb, gdje je ostao sve do svoje smrti. Sebastijan Žepič oženio se u Varaždinu, supruga je po rođenju nosila prezi-

57 Ljubomir Andrej LISAC, „Wurner, Mihael (1829-1891)“, Slovenska biografija. Slovenska akademija znanosti in umetnosti, Znanstvenoraziskovalni center SAZU, 2013. http://www.slovenska-biografija. si/oseba/sbi847442/\#slovenski-biografski-leksikon (15. ožujak 2020.).

58 Fran KOVAČIČ, „Luka Zima“, Časopis za zgodovino in narodopisje, Univerza v Mariboru, Zgodovinsko društvo v Mariboru, br. 3, Maribor, 1906., 91.

59 Fran ILEŠIČ, Josip KRIŽAN, „Životopis Luke Zime“, Ljubljanski zvon, Tiskovna zadruga, br. 6, Ljubljana, 1910., 375.

60 Fran CELESTIN, „Sebastijan Žepič“, Ljubljanski zvon, Tiskovna zadruga, br. 2, 1883., 129. 
me Weidlich. Žepiča se opisivalo kao profesora kojem je škola bila „kao ptici zrak, ali kao i ribi voda". ${ }^{61}$ Pisao je za Mohorjevo družbo koja je 1852-53. izdala njegov "Slovenski Grofine“. Za "Novice“ je napisao članak o slovenskom naglasku. Za slovenske gimnazije je sastavio "Latinsko- slovenske vaje za I. in II. razred“, za hrvatske „Lat-hrv. vježbenicu za II. razred". U rukopisu je dovršio iste vježbe za III. razred, tako je i pripremio za tisak „Lat-hrvatski rječnik za škole“. Također je pripremio za tisak zbirku „Stari hrvatski pisci“ koju je izdala Jugoslavenska akademija te je za veliki akademijski „Rječnik“ pripremio gradivo.

\section{ZAKLUUČAK}

Intelektualne i obrazovne slovensko-hrvatske veze u povijesti bile su vrlo izražene. Ta se povezanost očituje i u ovom radu, gdje je prikazano djelovanje slovenskih profesora u Varaždinskoj gimnaziji. lako je evidentirano djelovanje većeg broja slovenskih nastavnika u Varaždinskoj gimnaziji, nije bilo moguće pronaći podatke za sve njih. Za neke od njih teško je sa sigurnošću tvrditi da su Slovenci, ali su često sami za sebe govorili da su „Štajerci“. Neki od navedenih profesora, koji se ovdje spominju, pronalazimo i u drugim školama i gimnazijama na području Hrvatske. Bilo je uobičajeno da profesori dekretom odlaze u druge krajeve nekadašnje Austro-Ugarske Monarhije.

$\mathrm{U}$ radu je poimence navedeno i prikazano djelovanje 16 profesora koji su bili rođeni na području današnje Slovenije, iako je zapravo njihov broj bio veći. Njihovo djelovanje se uglavnom vezuje za različite krajeve današnje Hrvatske, neki su bili aktivniji u Varaždinu, a neki u Osijeku ili pak u Rijeci. Ono što je važno napomenuti jest to, da su navedeni nastavnici u Varaždinu djelovali različiti broj godina. Nažalost, ova tema do sada nije bila detaljnije istražena ni među slovenskim ni hrvatskim istraživačima. Može se pretpostaviti nekoliko razloga zbog kojih tema do sada nije naišla na veći interes. Nastavnici koji su radili u Varaždinskoj gimnaziji često su bili samozatajni pa se nisu osobito isticali u javnosti. Stoga postoji relativno mali broj izvora s kojima istraživači mogu raspolagati. Profesori nisu radili samo u Varaždinskoj gimnaziji, već su djelovali u različitim krajevima Austro-Ugarske Monarhije, pa su i podaci o njima razasuti u mnogim drugim školama. lako za sve navedene profesore nije bilo moguće odrediti njihov doprinos Varaždinu i Varaždinskoj gimnaziji svejedno ih je potrebno navesti jer su svojim djelovanjem u većoj ili manjoj mjeri su oblikovali hrvatsku kulturnu povijest Varaždina, te su utjecali na povijest

61 Isto. 
BARBARA RIMAN, JULIJA JANČEC: Slovenski profesori u Varaždinskoj gimnaziji s posebnim osvrtom na...

hrvatskog školstva kakvim ga mi danas poznajemo. Svakako je ovaj rad potrebno promatrati kao poziv mlađim generacijama povjesničara da novim, suvremenim metodama istraživanja iznađu podatke s kojima će biti lakše ocijeniti važnost slovenskih profesora u Varaždinskoj gimnaziji kroz povijest.

\section{LITERATURA}

1/ Valentin CAJNKO, „Ženidbeni običaji”, Zbornik za narodni život i običaje Južnih Slavena, Jugoslavenska akademija znanosti i umjetnosti, ur. Ivan MILČETIĆ, Zagreb, 1896., 178-184.

2/ Fran CELESTIN, „Sebastijan Žepič“, Ljubljanski zvon, Tiskovna zadruga, br. 2., Ljubljana, 1883., 129.

3/ Đurđica CESAR, „Društveno-političke prilike u Varaždinu 60-tih i 70-tih godina XIX.st.", Radovi Zavoda za znanstveni rad HAZU Varaždin, Zavod za znanstveni rad HAZU u Varaždinu, br. 25., Varaždin, 2014., 275-296.

4/ Đurđica CESAR, „Povijest Varaždinske gimnazije u prvoj polovini XX. st.“, u: Franjo Košćec i njegovo djelo: 1882.-1968., Zbornik radova sa znanstvenog skupa održanog 13. i 14. studenoga 2008. u Varaždinu, Hrvatska akademija znanosti i umjetnosti, Zavod za znanstveni rad HAZU Varaždin, Gradski muzej Varaždin, Gimnazija; [s. I.] : Hrvatsko entomol. društvo, gl. ur. Miroslav ŠıCEL, Branko SPEVEC, Varaždin, 2008., 15-23.

5/ Anton CUVAJ, Građa za povijest školstva, sv. 10., Trošak i naklada Kr. hrv-slavdalm. zem. vlade, Odjela za bogošt. i nastavu, Zagreb, 1910.

6/ Anton CUVAJ, Građa za povijest školstva, sv. 4., Trošak i naklada Kr. hrv-slavdalm. zem. vlade, Odjela za bogošt. i nastavu, Zagreb, 1910.

7/ Anton CUVAJ, Građa za povijest školstva, sv. 5., Trošak i naklada Kr. hrv-slavdalm. zem. vlade, Odjela za bogošt. i nastavu, Zagreb, 1910.

8/ Irena GANTAR GODINA, „Slovenski intelektualci- Izseljenci na Hrvaškem: Jernej Francelj (1846-1921)“, Dve domovini, ZRC SAZU, Inštitut za slovensko izseljenstvo in migracije, br. 24.,Varaždin, 2006., 165-183.

9/ Siniša HORVAT, „Prosvjetni i kulturni rad profesora Josipa Križana“, Časopis za suvremenu povijest, Hrvatski institut za povijest, br. 1, 2003., 249-258.

10/ Siniša HORVAT, „Knjižnica varaždinske gimnazije“, Historia Varasdiensis, Društvo povjesničara grada Varaždina i Varaždinske županije, br. 1., Varaždin, 2011., 215-241.

11/ Vladimir HUZJAN, "Slovenci u Varaždinu tijekom 1941. i 1942. godine“, Razprave in gradivo, Inštitut za narodnostna vprašanja, br. 82, 2019, 85-109. 
12/ Fran ILEŠIČ , Josip KRIŽAN, „Životopis Luke Zime“, Ljubljanski zvon, Tiskovna zadruga, br. 6, 1910., 375.

13/ Silvin JERMAN, Slovenci Karlovcu Karlovac Slovencima 1579.-2009., Kulturno društvo Slovenski dom Karlovac, Gradska knjižnica "Ivan Goran Kovačić", Karlovac, 2012., 24-27.

14/ Danijela JURČIĆ-ČARGO, „Slovenci na Hrvatskoj gimnaziji u Pazinu od 1899. do 1918.", Hrvatska gimnazija u Pazinu 1899.-1999., Zbornik radova s međunarodnog znanstvenog skupa u povodu prve Hrvatske gimnazije u Istri, Zagreb - Pazin, 28.-30. listopada 1998., Gimnazija i strukovna škola Jurja Dobrile, Josip ŠIKLIĆ, Pazin, 1999., 367-382.

15/ Franci JUST, „Panonski portreti : iz slovstvene preteklosti med Rabo in Dravo. 55, Valentin Cajnko", u: Vestnik, br. 40, 1998., 15.

16/ Stanislav JUŽNIČ, "Isusovački stručnjaci u Varaždinu.", Radovi Zavoda za znanstveni rad Varaždin, Hrvatska akademija znanosti i umjetnosti Zavod za znanstveni rad u Varaždinu, br. 26., Varaždin, 2015., 135-160.

17/ France KOBLAR, Četrta stran trikotnika: znameniti Slovenci in slovenska društva v Bosni in Hercegovini 1878.-2000., Mladinska knjiga, Ljubljana, 2008., 16-17.

18/ France KOBLAR, „Mandelc, Valentin (1837.-1872.)“, Slovenska biografija. Slovenska akademija znanosti in umetnosti, Znanstvenoraziskovalni center SAZU, 2013. http://www.slovenska-biografija.si/oseba/sbi346226/\#slovenski-biografski-leksikon (16. ožujak 2020.).

19/ France KOBLAR, „Starè, Josip (1842.-1907.)“, Slovenska biografija. Slovenska akademija znanosti in umetnosti, Znanstvenoraziskovalni center SAZU, 2013. http://www.slovenska-biografija.si/oseba/sbi604184/\#slovenski-biografski-leksikon (16. ožujak 2020.).

20/ Fran KOVAČIČ, „,Luka Zima“, Univerza v Mariboru, Zgodovinsko društvo v Mariboru, Časopis za zgodovino in narodopisje, br. 3, Maribor, 1906., 91.

21/ Ivan KRIŽAN, „Jarnej Francelj,“ Kres, Tiskarna Družbe sv. Mohorja, br. 8., Ljubljana, 1885., 419-420.

22/ Vera KRŽIŠNIK-BUKIĆ, „O Slovencih in slovenstvu na Hrvaškem od nekdaj do danes", Slovenci na Hrvaškem: dediščina in sedanjost, Zbornik referatov s posveta „Etnološka dediščina in kulturna podoba Slovencev na Hrvaškem“, Slovensko etnološko društvo, gl. ur. Katalin MUNDA HIRNOK i Mojca RAVNIK, Ljubljana, 2006., 15-87.

23/ Branka LEPEN, „Dijaki iz Ormoža in njegove širše okolice na Varaždinski gimnaziji v letih od 1851. do 1914.", Ormož skozi stoletja IV, Skupščina Občine Ormož, gl. ur. Peter Pavel KLASNIC, Ormož, 1993., 175-185. 
BARBARA RIMAN, JULIJA JANČEC: Slovenski profesori u Varaždinskoj gimnaziji s posebnim osvrtom na...

24/ Emilijan LILEK, Slovenski v tujini službojoči šolniki, Samozaložba, Celje, 1933., 55.

25/ Ljubomir Andrej LISAC, „Selak, Franjo (1847.-1906.)“, Slovenska biografija. Slovenska akademija znanosti in umetnosti, Znanstvenoraziskovalni center SAZU, 2013. http://www.slovenska-biografija.si/oseba/ sbi558698/\#slovenski-biografski-leksikon (16. ožujak 2020.).

26/ Ljubomir Andrej LISAC, „Senekovič, Martin (1837.-1919.)“, Slovenska biografija. Slovenska akademija znanosti in umetnosti, Znanstvenoraziskovalni center SAZU, 2013. http://www.slovenska-biografija.si/oseba/ sbi561764/\#slovenski-biografski-leksikon (5. ožujak 2020.).

27/ Ljubomir Andrej LISAC, „Valjavec, Peter (1846.-1909.)“, Slovenska biografija. Slovenska akademija znanosti in umetnosti, Znanstvenoraziskovalni center SAZU, 2013. http://www.slovenska-biografija.si/oseba/ sbi758994/\#slovenski-biografski-leksikon, (15. ožujak 2020.).

28/ Ljubomir Andrej LISAC, „Wurner, Mihael (1829.-1891.)“, Slovenska biografija. Slovenska akademija znanosti in umetnosti, Znanstvenoraziskovalni center SAZU, 2013. http://www.slovenska-biografija.si/oseba/ sbi847442/\#slovenski-biografski-leksikon (15. ožujak 2020.).

29/ Janez LOGAR, „Trdina, Janez (1830.-1905.)“, Slovenska biografija, Slovenska akademija znanosti in umetnosti, Znanstvenoraziskovalni center SAZU, Ljubljana, 2013. http://www.slovenska-biografija.si/oseba/ sbi719555/\#slovenski-biografski-leksikon (11. 3. 2020.).

30/ Josip MAL, „Bradaška, Franjo (1829.-1904.)“, Slovenska biografija. Slovenska akademija znanosti in umetnosti, Znanstvenoraziskovalni center SAZU, Ljubljana, 2013. http://www.slovenska-biografija.si/oseba/ sbi147766/\#slovenski-biografski-leksikon (5. ožujak 2020.).

31/Vilko NOVAK, Jože TOPORIŠıč, „Valjavec, Matija (1831.-1897.)“, Slovenska biografija. Slovenska akademija znanosti in umetnosti, Znanstvenoraziskovalni center SAZU, 2013. http://www.slovenska-biografija.si/oseba/ sbi758091/\#slovenski-biografski-leksikon (15. ožujak 2020.).

32/ Ivan OBADIĆ, „Pregled historiografskih radova o Gradu Varaždinu - prilog za bibliographiu Warasdiensis“, Radovi Zavoda za znanstveni rad HAZU Varaždin, Hrvatska akademija znanosti i umjetnosti Zavod za znanstveni rad u Varaždinu, br. 20., Varaždin, 2009., 129-193.

33/ Janko OROŽEN, „Valenčak, Martin (1834.-1887.)“, Slovenska biografija. Slovenska akademija znanosti in umetnosti, Znanstvenoraziskovalni center SAZU, 2013. http://www.slovenska-biografija.si/oseba/sbi754627/\#slovenski-biografski-leksikon (15. ožujak 2020.). 
34/ Vladimir PLETENAC, „Varaždinska gimnazija od 1636. do kraja prvog svjetskog rata“, Gimnazija - SC „Gabriel Santo“ Varaždin 1636. - 1986., Savjet SC "Gabriel Santo", gl. ur. Josip Runjak, Varaždin, 1986., 49-96.

35/ Jože POGAČNIK, „Matija Valjavec i njegovo književno djelo”, Radovi Zavoda za znanstveni rad Varaždin, Hrvatska akademija znanosti i umjetnosti Zavod za znanstveni rad u Varaždinu, br. 14-15, Varaždin, 2004., 145-153.

36/ Barbara RIMAN, „Slovenski profesori u Carsko-kraljevskoj velikoj državnoj gimnaziji u Pazinu", Acta Histriae, Zgodovinsko društvo za južno Primorsko Koper, br. 2., Koper, 2016., 357-380.

37/ Barbara RIMAN, Kristina RIMAN, „Hrvatarji u slovenski književnosti“, Slavistična revija, br. 3, Slavistično društvo Slovenije, Ljubljana, 2016., 315-324.

38/ Barbara RIMAN, Kristina RIMAN, „Slovenci u Hrvatskoj gimnaziji u Zadru od 1897. do 1921. godine", Zgodovinski časopis, Zveza zgodovinskih društev Slovenije, br. 3-4, Ljubljana, 2016., 338-363.

39/ Kristina RIMAN, „Hrvatsko-slovenske veze u putopisima Josipa Starea“, Slavistična revija, Slavistično društvo Slovenije, br. 1., Ljubljana, 2017., 169-182.

40/ Kristina RIMAN, „Slovenski pisci u Hrvatskoj kao graditelji slovensko-hrvatskih odnos", Razprave in gradivo: revija za narodnostna vprašnja, Inštitut za narodnostna vprašanja, , br. 80, Ljubljana, 2018., 43-64.

41/ Viktor SMOLEJ, „Zapisek o Valjavcu“, Jezik in slovstvo, Zveza društev Slavistično društvo Slovenije, br. 1.,Ljubljana, 1983., 24-29.

42/ Viktor SMOLEJ, „Scheidela, Hinko (1874.-1912.)“, Slovenska biografija. Slovenska akademija znanosti in umetnosti, Znanstvenoraziskovalni center SAZU, 2013. http://www.slovenska-biografija.si/oseba/sbi540647/\#slovenski-biografski-leksikon (5. ožujka 2020.).

43/ Marija STATONIK, "Matija Valjavec”, Traditiones, Inštitut za slovensko narodopisje ZRC SAZU, br. 27, Ljubljana, 1998., 271-273.

44/ Janko ŠLABINGER, „Cajnko, Valentin (1868.-1925.)“, Slovenska biografija. Slovenska akademija znanosti in umetnosti, Znanstvenoraziskovalni center SAZU, Ljubljana, 2013. http://www.slovenska-biografija.si/oseba/ sbi154856/\#slovenski-biografski-leksikon (5. ožujak 2020.).

45/ Janko ŠLABINGER, „Francelj, Jernej (1821.-1889.)“, Slovenska biografija. Slovenska akademija znanosti in umetnosti, Znanstvenoraziskovalni center SAZU, 2013. http://www.slovenska-biografija.si/oseba/sbi191156/\#slovenski-biografski-leksikon (16. ožujak 2020.).

46/ Filip ŠKILJAN, Slovenci u Varaždinu i Varaždinskoj županiji, Slovensko kulturno društvo Nagelj, 2015. 
47/ Filip ŠKILJAN, Aleksandar VUKIĆ, „Migracije Slovenaca na području sjeverozapadne Hrvaske (Varaždinska i Krapinsko-zagorska županija), Podravina, Izdavačka kuća Meridijani, br. 14, 175-189.

48/ Branko ŠUŠTAR, „Poklicne migracije slovenskega učiteljstva od habsburških do jugoslovanskih časov", Migracije in slovenski prostor od antike do danes, Zveza zgodovinskih društev Slovenije, Peter ŠTIH, gl. ur. Bojan BALKOVEC, Ljubljana, 2010., 209-224.

49/ Janez TRDINA, Bachovi Huzarji in Ilirci: spomini iz moje profesorske službe na Hrvaškem (1853-1867), Schwentner, Ljubljana, 1903., 7.

50/ Anton TRSTENJAK, Spomenik slovenske uzajemnost, Samozaložba, Ljubljana, 1886., 110-111.

51/ Miroslav VANINO, Isusovci i hrvatski narod, Filozofsko-teološki institut Družbe Isusove, Zagreb, 1987.

\section{Internet}

1/ https://revija.ognjisce.si/revija-ognjisce/27-obletnica-meseca/1884-josipstare (16. ožujak 2020.)

2/ http://hbl.lzmk.hr/clanak.aspx?id=6225 (20. veljače 2020.)

3/ http://enciklopedija.hr/natuknica.aspx?id=63799 (15. ožujak 2020.). 


\section{SUMMARY}

\section{SLOVENIAN PROFESSORS AT THE VARAŽDIN GRAMMAR SCHOOL WITH SPECIAL REFERENCE TO THE PERIOD OF THE AUSTRO-HUNGARIAN MONARCHY}

Slovene-Croatian ties in the history of education remain an unresearched topic in Slovene-Croatian history and history in general. The history of Slovenianhood in the Croatian territory has recently begun to be researched, but the topic related to education seems to have been of little importance and interest to Croatian and Slovenian researchers. In fact, professors have, in this scientific segment, have been neglected by the researchers. For this reason, this article provides an overview of the activities of Slovene professors who worked at the grammar school in Varaždin. The grammar school in Varaždin, just like some others grammar schools in Croatia, played a significant role in Croatian history, and, in addition to professors born in Slovenian regions, a large number of pupils from Slovenian regions were also recorded.

This paper will not present the activities of all Slovenian professors present at the grammar school in Varaždin, because it was not possible to find even the basic information about some of them. However, the work and activities of 16 professors, who worked at the grammar school during the period of Austro-Hungarian Monarchy, will be presented. The basic information were taken from Emilian Lilek's book as well as older literature (Anton Cuvaj) and secondary sources.

The paper devotes special attention to the professors' co-shaping of Croatian education through history. Professors mentioned in the paper are: Franjo Bradaška, Valentin Cajnko, Jernej (Bartol) Francelj, Josip Križan, Valentin Mandelc, Anton Rajšp, Franjo Selak, Josip Stare, Janez (Ivan) Trdina, Hinko Scheidela, Martin Senekovič, Matija Valjavec, Peter Valjavec, Martin Valenčak, Mihael Wurner, Luka Zima, and Sebastijan Žepič.

Key Words: Slovene-Croatian ties; Grammar school in Varaždin; Slovenes in Croatia; Slovenian professors. 
